\title{
ETHNOMEDICINAL NOTES AND CHROMOSOMAL STATUS OF SOME SELECTED HERBS FROM PARVATI VALLEY, KULLU DISTRICT, HIMACHAL PRADESH
}

\author{
HIMSHIKHA, RAGHBIR CHAND GUPTA, VIJAY KUMAR SINGHAL*, ROHIT KUMAR \\ Department of Botany, Punjabi University, Patiala, Punjab, India 147002 \\ Email: vksinghal53@gmail.com
}

Received: 25 Jul 2017 Revised and Accepted: 31 Aug 2017

\begin{abstract}
Objective: The objective of the present study was to enlist the ethnobotanical uses and chromosomal status of wild plants of Parvati Valley, Himachal Pradesh. Plants are locally used in curing ulcers, sores, insect bites, muscular and joint pains, pneumonia, jaundice, diarrhoea, piles, swellings, allergies and skin diseases.
\end{abstract}

Methods: For documentation of ethnomedicinal information, a questionnaire containing the vernacular name, plant part/s used, medicinal uses, mode of preparation and amount of dose taken was prepared. Personnel interviews/interactions were conducted with medicine men (vaids and hakims), local healers, village elders, tribals and shepherds. The interviews were cross-validated to ascertain the facts about the local use of each plant species. Chromosomal status was determined through male meiosis by using standard acetocarmine technique.

Results: Present paper contains information on ethnomedicinal uses, chromosome counts, male meiosis and pollen fertility on 62 medicinal herbs from Parvati Valley. Plants are used as a decoction, paste or powder in cooked form or as raw. Preparations are taken orally in pure form or as a mixture or with a little amount of salt, milk, honey or butter.

Conclusion: Due to indiscriminate forest clearing, grazing and collection by traders, most of the species became rare and restricted to specific pockets or are now almost extinct. To preserve herbal diversity, grazing should be restricted in alpine and sub-alpine zones. Database on ethnic knowledge, chromosomal diversity, natural regeneration and distribution pattern should be prepared for designing future plans for sustainable development.

Keywords: Ethnobotany, Chromosomal status, Medicinal herbs, Parvati valley, Himachal Pradesh

(C) 2017 The Authors. Published by Innovare Academic Sciences Pvt Ltd. This is an open access article under the CC BY license (http://creativecommons.org/licenses/by/4.0/) DOI: http://dx.doi.org/10.22159/ijpps.2017v9i10.21611

\section{INTRODUCTION}

Parvati Valley situated along the river Parvati in Kullu district (Himachal Pradesh is approx. $130 \mathrm{~km}$ long and $1.5 \mathrm{~km}$ wide. The altitude ranges between $1100 \mathrm{~m}$ at Bhuntar town to $4100 \mathrm{~m}$ at Mantalai Lake. Upper parts of the valley represent the Rocky Mountains and high peaks with glaciers while the lower regions are greener. Climate varies from hot and sub-tropical in the southern lower tracts $(600-900 \mathrm{~m})$ to warm temperate $(900-1800 \mathrm{~m})$, cool temperate (1900-2400 m) and cold alpine to glacial (2400-4800 m) in the northern and eastern mountain ranges. Valley which experiences high rainfall $(800-900 \mathrm{~mm})$ and heavy snowfall $(8-9 \mathrm{~m})$ supports dense forest of 'pines', 'deodar', 'oaks', 'spruce', 'fir', 'alder' and 'rhododendron'. The vegetation comprises a number of annual and perennial herbs of Anemeone, Aquilegia, Astragalus, Gentiana, Geranium, Lactuca, Leucas, Polygonum, Potentilla, Rumex, Saussurea, Taraxacum and Thymus. Shrubby elements comprise species of Artemisia, Berberis, Desmodium, Hippophae, Juniperus, Lonicera, Prinsepia, Rosa and Rubus. Plants of immense medicinal value include Aconitum heterophyllum, Ajuga bracteosa, Arcticum lappa, Berberis sp., Cannabis sativa, Centella asiatica, Datura stramonium, Gentiana sp., Geranium sp., Plantago sp., Viola canescens, Withania somnifera and Zanthoxylum armatum. History of herbal medicines in India is the oldest and richest and most of the cultural conditions are associated with the use of medicinal plants in traditional systems of medicine. Even today most of the tribal communities are dependent upon local traditional healing system for their primary health care. And during the last $100 \mathrm{y}$ or so, the science of ethnobotany has progressed at a much faster rate and the trend is shifting from mere documentation to a more practical one emphasizing on conservation and sustainable use of herbal resources [1-3]. Though studies have been made by some researchers to collect data on ethnobotany from Parvati Valley [4-6], no attempt has been made to analyze the cytomorphological variation in the medicinal herbs. Same kind of ethnobotanical studies was conducted from other parts of the India
[7-10]. Present studies were carried out with an aim to document the traditional knowledge about herbal drugs, a method of preparation and amount and use of drug against diseases. The purpose was also to know the chromosomal status, male meiotic course and pollen fertility and natural regeneration of locally used wild herbs.

\section{MATERIALS AND METHODS}

\section{Field surveys}

The valley has been visited consecutively for five years between 2009-2013 during the months of April-October to survey all the possible habitats and inhabitants.

\section{Ethnomedicinal information}

For documentation of ethnomedicinal information, a questionnaire containing the vernacular name, plant part/s used, medicinal uses, mode of preparation and amount of dose taken was prepared. Personnel interviews/interactions were conducted with medicine men (vaids and hakims), local healers, village elders, tribals and shepherds. The interviews were cross-validated to ascertain the facts about the local use of each plant species.

\section{Plant identification}

Plants were identified in the field by their vernacular names and by consulting the flora [11]. Besides, the ample accessions were also compared to the specimens lying in the herbaria, Department of Botany, Punjabi University, Patiala, Botanical Survey of India, Northern circle, Dehra Dun and Forest Research Institute, Dehra Dun. Well identified accessions were submitted as vouchers in the herbarium, Department of Botany, Punjabi University Patiala (PUN).

Chromosome counts, male meiosis and pollen viability

Chromosomal status was determined through male meiosis for which young and unopened floral buds/inflorescences were fixed in 
a freshly prepared Carnoy's fixative (A mixture of ethanol, chloroform and glacial acetic acid (in the volume ratio of 6:3:1) for $24 \mathrm{~h}$ and preserved in 70\% ethanol. Anthers were squashed in $1 \%$ acetocarmine and meiocytes were observed at different stages of meiosis. Pollen viability was estimated through stainability tests using glycerol-acetocarmine (1:1) mixture. Well-filled pollen grains with fully stained nuclei/cytoplasm were taken as apparently fertile while those with partially stained cytoplasm or unstained and shrivelled nature were counted as sterile.

\section{Microphotographs}

Best plates of chromosome counts, meiotic abnormalities, spores and pollen grains (fertile and sterile) were photographed from the temporary mounts with Digital Imaging System of Nikon Eclipse 80i microscope and Leica Qwin Imaging system.

\section{Natural regeneration}

Natural regeneration of species was ascertained from the new plants emerging out from the seeds in the vicinity of the adult population. Vegetative propagation, if any, was confirmed from the new shoots coming out from the underground parts. To confirm the mode of origin, the area around the root of an individual plant was also dug out.

\section{RESULTS AND DISCUSSION}

\section{A. Ethnobotany}

Paper encompasses ethnomedicinal information, chromosome counts, male meiosis, pollen viability and natural regeneration of locally used 62 medicinal herbs. Data provided in table 1 include the species with voucher number, vernacular name, chromosome number, plant part/s used and ethnomedicinal uses. Data revealed that locals used herbs in the treatment of various ailments/disorders such as ulcers, sores, insect bites, muscular and joint pains, pneumonia, jaundice, diarrhoea, tuberculosis, piles, swellings, allergies and skin diseases. For treating various ailments, the locals use different plant parts. Among the aerial parts used for curing health disorders, leaves $(30.61 \%)$ were the most commonly used (fig. 1a). Other plant parts used as a herbal drug are a whole plant $(24.49 \%)$, roots $(18.37 \%)$, seeds $(9.18 \%)$, flowers
(8.17\%), fruits (6.13\%) and rhizome, stem and bark (1.02\%). Among different categories of plants used, the maximum numbers of species yielding drugs are herbs (59\%), followed by shrubs $(28 \%)$ and trees (13\%; fig. 1b).

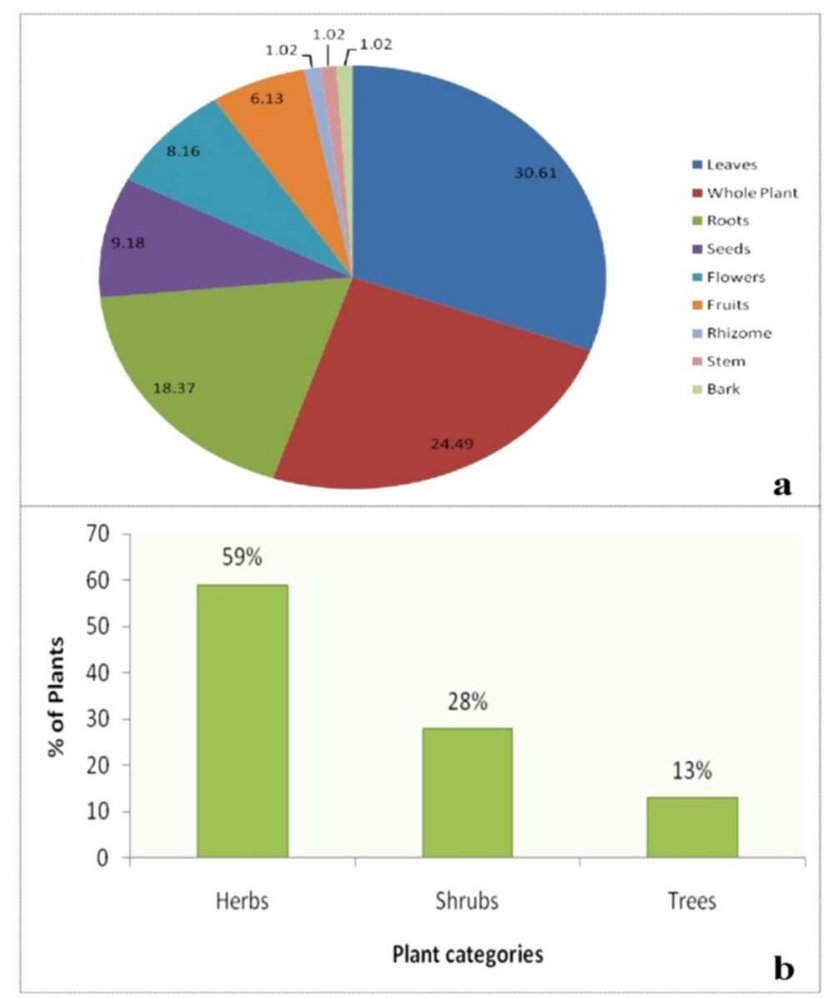

Fig. 1: a) Pie chart showing percentage of different plant parts used, b) Histogram showing categories of plants used

Table 1: Ethnobotanical information gathered for plant species from the parvati valley in kullu district (Himachal Pradesh)

\begin{tabular}{|c|c|c|c|c|}
\hline S. No. & $\begin{array}{l}\text { Species with voucher (PUN) } \\
\text { \& chromosome number (n) }\end{array}$ & $\begin{array}{l}\text { Vernacular } \\
\text { name/s }\end{array}$ & $\begin{array}{l}\text { Plant part } / \mathrm{s} \\
\text { used }\end{array}$ & Medicinal uses and mode of preparation \\
\hline \multirow[t]{2}{*}{1.} & $\begin{array}{l}\text { Achillea millefolium } \\
\text { L. } / 57159 / 2 \mathrm{n}=18\end{array}$ & Birangesif & Leaves & $\begin{array}{l}\text { Leaves are highly tonic. They are crushed and cure dysentery, } \\
\text { urinary problems, toothache and swellings. }\end{array}$ \\
\hline & & & Flowers & $\begin{array}{l}\text { Flowers are antiseptic, aromatic, carminative, laxative, stimulant } \\
\text { and diuretic, used to cure gastric problems, measles, fever, piles } \\
\text { and diabetes. }\end{array}$ \\
\hline \multirow[t]{2}{*}{2.} & $\begin{array}{l}\text { Aconitum heterophyllum } \\
\text { Wall./57323/2n=16 }\end{array}$ & Ateesh-Pateesh & Root & $\begin{array}{l}\text { Dry root is powdered, taken orally with lukewarm water twice a day to } \\
\text { cure a toothache, fever, cough, stomachache, rheumatism, diarrhoea. }\end{array}$ \\
\hline & & & Leaves & Leaves help in acute inflammation, cough, hysteria, giardiasis and piles. \\
\hline 3. & $\begin{array}{l}\text { Agrimonia eupatoria } \\
\text { L. } / 57945 / 2 \mathrm{n}=56 \\
58037 / 2 \mathrm{n}=84\end{array}$ & Agrimony & Whole plant & $\begin{array}{l}\text { An infusion of the whole plant is used in the treatment of jaundice, } \\
\text { diarrhoea, cold, fever and acts as a blood purifier. }\end{array}$ \\
\hline 4. & $\begin{array}{l}\text { Ajuga parviflora } \\
\text { Benth./57166/2n=32 }\end{array}$ & Neelkanthi & Leaves & $\begin{array}{l}\text { Decoction prepared from leaves is taken as a blood purifier and } \\
\text { cure stomach problems. Leaf juice is used to treat earache, eye } \\
\text { ache, throat ache, boils and gums. Also used for malarial fever, } \\
\text { jaundice. Leaf powder is used to cure ulcers of mouth. }\end{array}$ \\
\hline 5. & $\begin{array}{l}\text { Androsace rotundifolia } \\
\text { Hardw. } / 58668 / 2 \mathrm{n}=20\end{array}$ & - & Rhizome & $\begin{array}{l}\text { The extract of the rhizome mixed with salt is used as eye drops for } \\
\text { curing cataract. }\end{array}$ \\
\hline 6. & $\begin{array}{l}\text { Anemone rivularis Buch.-Ham. } \\
\text { ex DC. } / 58346 / 2 \mathrm{n}=16\end{array}$ & Angeli & $\begin{array}{l}\text { Root } \\
\text { Whole plant }\end{array}$ & $\begin{array}{l}\text { A decoction of the root is applied externally to cuts and wounds. } \\
\text { Paste prepared from the whole plant is used to treat a cough and } \\
\text { fever. }\end{array}$ \\
\hline 7. & Arctium lappa L./56091/2n=36 & Jangli Kuth & Root & Root is diuretic, helps in reducing blood sugar. \\
\hline 8. & $\begin{array}{l}\text { Artemisia scoparia Waldst. and } \\
\text { Kit./ } 57225 / 2 \mathrm{n}=18\end{array}$ & Shaheen & Leaves & $\begin{array}{l}\text { Leaves are crushed, mixed in the urine of the cow and used against } \\
\text { piles. Crushed leaves when snuffed give relief from a headache. }\end{array}$ \\
\hline \multirow[t]{3}{*}{9.} & Berberis glaucocarpa & Daruhaldi, & Flowers & Flowers are boiled in water, used for acidity. \\
\hline & Stapf./56046/2n=28 & Shambhar & Fruits & Fruits are taken as laxative and anti-scorbutic. \\
\hline & & & Roots & $\begin{array}{l}\text { Roots boiled in water and filtered and use as an eye drop. A } \\
\text { decoction of the root is used for treating swollen gums and } \\
\text { toothache. }\end{array}$ \\
\hline 10. & Bidens pilosa $\mathrm{L} . / 56323 / 2 \mathrm{n}=72$ & Ajeran & Whole plant & $\begin{array}{l}\text { Plant juice is used for cuts, sores and wounds, diarrhoea, headache } \\
\text { and skin diseases. }\end{array}$ \\
\hline
\end{tabular}




\begin{tabular}{|c|c|c|c|c|}
\hline 11. & $\begin{array}{l}\text { Cannabis sativa } \\
\text { L. } / 57928 / 2 \mathrm{n}=20\end{array}$ & Bhang & $\begin{array}{l}\text { Seeds } \\
\text { Whole plant } \\
\text { Leaves }\end{array}$ & $\begin{array}{l}\text { Warm seed oil is used for massage against arthritis. } \\
\text { Whole plant is used as a pain-killer and sleeps inducer and relieves } \\
\text { from nausea, cold, cough and bronchitis. } \\
\text { Crushed leaves used to cure piles, cuts, ulcers and skin eruptions. }\end{array}$ \\
\hline 12. & $\begin{array}{l}\text { Clematis connata } \\
\text { DC. } / 57233 / 2 \mathrm{n}=16\end{array}$ & Kuja & Leaves & $\begin{array}{l}\text { Leaves are crushed and juice is extracted. The juice is then inhaled } \\
\text { to relieve from Sinusitis, indigestion and ulcers. }\end{array}$ \\
\hline 13. & $\begin{array}{l}\text { Clematis grata } \\
\text { Wall./ } 57223 / 2 \mathrm{n}=16\end{array}$ & Dhand & Leaves & $\begin{array}{l}\text { Paste of leaves is very useful on boils and heals joint fractures. Its } \\
\text { decoction is also used for jaundice. }\end{array}$ \\
\hline 14. & $\begin{array}{l}\text { Conyza stricta } \\
\text { Willd./57201/2n=18 }\end{array}$ & Batt dawna & Whole plant & Used for bone fracture. \\
\hline 15. & $\begin{array}{l}\text { Corydalis thyrsiflora } \\
\text { Prain } / 57175 / 2 \mathrm{n}=14\end{array}$ & Bhootkashi & Whole plant & Plant juice is used in mental disorders. \\
\hline 16. & $\begin{array}{l}\text { Cuscuta reflexa } \\
\text { Roxb./57163/2n=32 }\end{array}$ & $\begin{array}{l}\text { Akashbail, } \\
\text { Niladhary }\end{array}$ & Whole plant & $\begin{array}{l}\text { Plant juice mixed with 'til'oil used for treatment of hair fall and } \\
\text { rheumatic pains. }\end{array}$ \\
\hline 17. & $\begin{array}{l}\text { Cynoglossum lanceolatum } \\
\text { Forssk./57179/2n=24 }\end{array}$ & - & Root Leaves & $\begin{array}{l}\text { Roots with milk are used as a tonic for bronchitis. } \\
\text { Decoction of leaves is used as a blood purifier. }\end{array}$ \\
\hline 18. & $\begin{array}{l}\text { Datura stramonium } \\
\text { L. } / 57168 / 2 n=24\end{array}$ & Dhatura & $\begin{array}{l}\text { Leaves } \\
\text { Fruits }\end{array}$ & $\begin{array}{l}\text { Dried seeds are roasted, powdered and mixed with hot mustard oil to } \\
\text { make a paste. It is then applied on joints to relieve from arthritis } \\
\text { pains. Also 8-10 seeds are taken daily against urinary complaints and } \\
\text { asthma. Seed decoction used against fever and jaundice. } \\
\text { Roasted leaves are used to cure pain and applied on boils and sores. } \\
\text { Fruit juice applied on the scalp for curing dandruff and falling hairs, } \\
\text { stomach and eye problems. }\end{array}$ \\
\hline 19. & $\begin{array}{l}\text { Desmodium elegans } \\
\text { DC. } / 58384 / 2 \mathrm{n}=22\end{array}$ & White Khathi & Leaves & Crushed leaves applied on cuts and wounds. \\
\hline 20. & $\begin{array}{l}\text { Emblica officinalis } \\
\text { Gaertn./57187/2n=104 }\end{array}$ & Amla & $\begin{array}{l}\text { Root } \\
\text { Fruits } \\
\text { Whole plant }\end{array}$ & $\begin{array}{l}\text { Root is used as a tonic, stomachic and purifies blood. } \\
\text { Fruits are taken to cure cough, cold, anaemia, fever, piles, } \\
\text { constipation, diabetes, stomach, liver and eye complaints. } \\
\text { The whole plant is used in jaundice, asthma, typhoid fever and } \\
\text { wounds. }\end{array}$ \\
\hline 21. & $\begin{array}{l}\text { Eupatorium adenophorum } \\
\text { Spreng./ } 57324 / 2 \mathrm{n}=51\end{array}$ & Thrai & Leaves & Leaves paste are applied on cuts and wounds. \\
\hline 22. & $\begin{array}{l}\text { Fagopyrum dibotrys (D. Don) } \\
\text { Hara/58662/2n=16 }\end{array}$ & Kotu & Whole plant & The crushed plant is used against blood clotting. \\
\hline 23. & $\begin{array}{l}\text { Filipendula vestita (Wall. ex G. } \\
\text { Don) Maxim. } / 57205 / 2 \mathrm{n}=14\end{array}$ & - & Leaves & Crushed leaves used to stop bleeding. \\
\hline 24. & $\begin{array}{l}\text { Gentiana argentia (Royle ex D. } \\
\text { Don) DC. } / 56067 / 2 n=18\end{array}$ & Karoo & $\begin{array}{l}\text { Roots } \\
\text { Leaves }\end{array}$ & $\begin{array}{l}\text { Karoo prepared from roots and leaves is used as a blood purifier. } \\
\text { Leaves are boiled in water, given as filtrate for curing fever. }\end{array}$ \\
\hline 25. & $\begin{array}{l}\text { Geranium nepalense } \\
\text { Sweet } / 57333 / 2 n=28\end{array}$ & Rattanjot & $\begin{array}{l}\text { Whole plant } \\
\text { Leaves } \\
\text { Root }\end{array}$ & $\begin{array}{l}\text { Plant is highly astringent, used for a toothache, applied externally } \\
\text { on the eyes. } \\
\text { Leaf decoction used during fever, headache, and rheumatic pains. } \\
\text { Roots used for toothache, cuts, wounds and eye problems. }\end{array}$ \\
\hline 26. & $\begin{array}{l}\text { G. wallichianum D. Don ex } \\
\text { Sweet } / 58677 / 2 \mathrm{n}=28\end{array}$ & Gugatjot & Whole plant & Used to control stomachache, cough and throat infection. \\
\hline 27. & $\begin{array}{l}\text { Hypericum elodeoides } \\
\text { Choisy } / 57222 / 2 \mathrm{n}=18\end{array}$ & Vasanti & $\begin{array}{l}\text { Leaves } \\
\text { Root }\end{array}$ & $\begin{array}{l}\text { Leaf powder used as a febrifuge. } \\
\text { Root decoction is given to control vomiting. }\end{array}$ \\
\hline 28. & $\begin{array}{l}\text { Impatiens laxiflora } \\
\text { Edgew./57300/2n=14 }\end{array}$ & Hannu & Leaves & Leaf paste applied on cuts and wounds and gives relief from fever. \\
\hline 29. & $\begin{array}{l}\text { Lactuca dissecta } \mathrm{D} \text {. } \\
\text { Don } / 57174 / 2 \mathrm{n}=16\end{array}$ & Dodal & Root & A paste of roots used for skin diseases, syphilis, and rheumatism. \\
\hline 30. & $\begin{array}{l}\text { Leucas lanata } \\
\text { Benth./56097/2n=30 }\end{array}$ & Dhurlughas & Leaves & $\begin{array}{l}\text { Leaf infusion is given in diarrhoea and dysentery to cattle. Leaves } \\
\text { fried in 'ghee' are used to expel the placenta after delivery. }\end{array}$ \\
\hline 31. & $\begin{array}{l}\text { Lotus corniculatus } \\
\text { L./56051/2n=12 }\end{array}$ & - & Whole plant & Plant paste is used against skin inflammation. \\
\hline 32. & $\begin{array}{l}\text { Nepeta spicata } \\
\text { Benth./58664/2n=36 }\end{array}$ & Billilotan & $\begin{array}{l}\text { Leaves } \\
\text { Roots }\end{array}$ & $\begin{array}{l}\text { Leaves are used for cold, cough, fever, influenza and blood } \\
\text { pressure. Roots used as a diuretic. }\end{array}$ \\
\hline 33. & $\begin{array}{l}\text { Origanum vulgare } \\
\text { L./58027/2n=30 }\end{array}$ & Ban-ajwain & $\begin{array}{l}\text { Tubers } \\
\text { Leaves }\end{array}$ & $\begin{array}{l}\text { Tubers are used for epilepsy, cold, diarrhoea, uterine and kidney } \\
\text { stones, fever and colic disorder. } \\
\text { Leaf pastes along with pepper applied on boils, cuts, wounds, } \\
\text { ulcers and burns. }\end{array}$ \\
\hline 34. & $\begin{array}{l}\text { Plantago depressa } \\
\text { Willd./56082/2n=12 }\end{array}$ & Bartang & Seeds & Seeds used as a laxative. \\
\hline 35 & P. lanceolata L./52987/2n=12 & Isabagol & Seeds & $\begin{array}{l}\text { Seeds are taken with milk used to control irregular bowel } \\
\text { syndrome and constipation. }\end{array}$ \\
\hline 36. & P. major L./58040/2n=12 & Daruna, Durni & $\begin{array}{l}\text { Seeds } \\
\text { Leaves }\end{array}$ & $\begin{array}{l}\text { Powdered seeds mixed with sugar to reduce constipation } \\
\text { and stomach problems. } \\
\text { Leaf paste with mustard oil applied on cuts, boils, rashes, sores, } \\
\text { scratches. }\end{array}$ \\
\hline 37. & $\begin{array}{l}\text { Plectranthus rugosus Wall. ex. } \\
\text { Benth./57219/2n=24 }\end{array}$ & Patharchur & Leaves & $\begin{array}{l}\text { Leaves are burnt to repel fleas. Paste or juice of leaves is used } \\
\text { against a headache. }\end{array}$ \\
\hline 38. & $\begin{array}{l}\text { Punica granatum } \\
\text { L./56120/2n=16 }\end{array}$ & Daru & $\begin{array}{l}\text { Root } \\
\text { Seeds }\end{array}$ & $\begin{array}{l}\text { Fresh root decoction is taken orally once at morning for } 3-4 \mathrm{~d} \text { for } \\
\text { treating piles and to kill intestinal worms. Decoction of root acts as } \\
\text { an astringent and is used to cure fever, cough and cholera. }\end{array}$ \\
\hline
\end{tabular}




\begin{tabular}{|c|c|c|c|c|}
\hline 39. & $\begin{array}{l}\text { Ranunculus laetus Wall. ex } \\
\text { Royle } / 56064 / 2 \mathrm{n}=28\end{array}$ & Chambel booti & Leaves & $\begin{array}{l}\text { Fresh leaf paste is applied on skin for treating skin infections. } \\
\text { Frandice, alarnoea, }\end{array}$ \\
\hline 40. & $\begin{array}{l}\text { Rumex hastatus D. } \\
\text { Don } / 56065 / 2 \mathrm{n}=18\end{array}$ & $\begin{array}{l}\text { Khatimal, } \\
\text { Malora }\end{array}$ & $\begin{array}{l}\text { Root } \\
\text { Leaves }\end{array}$ & $\begin{array}{l}\text { Decoction of root with bark of Quercus leucotrichophora, when } \\
\text { cooked with wheat flour, sugar and ghee is given twice a day for } 4 \text { - } \\
5 \text { d during asthma, backache, rheumatism and weakness. } \\
\text { Leaf juice applied on cuts and wounds. }\end{array}$ \\
\hline 41. & $\begin{array}{l}\text { R. nepalensis } \\
\text { Spreng. } / 56056 / 2 \mathrm{n}=80\end{array}$ & Kharpoo & Roots & $\begin{array}{l}\text { Roots boiled in water applied externally for swellings of } \\
\text { muscles and joint pains. }\end{array}$ \\
\hline & $56057 / 2 n=120$ & & Whole plant & Plant juice used to stop to cut bleedings. \\
\hline 42. & $\begin{array}{l}\text { Senecio chrysanthemoides } \\
\text { DC. } / 57297 / 2 \mathrm{n}=40\end{array}$ & Chahl & Whole plant & $\begin{array}{l}\text { Plant powder is used as a blood purifier, rheumatic, gastric and } \\
\text { liver ailments. }\end{array}$ \\
\hline 43. & $\begin{array}{l}\text { Silene vulgaris }(\text { Moench) } \\
\text { Garcke } / 57403 / 2 \mathrm{n}=24 \\
57404 / 2 \mathrm{n}=48\end{array}$ & Ghadoli & Leaves & Fresh and leaves used against cough and asthma. \\
\hline 44. & $\begin{array}{l}\text { Solanum nigrum } \\
\text { L. } / 56359 / 2 \mathrm{n}=24\end{array}$ & Makoh & Leaves & $\begin{array}{l}\text { Leaves are chewed to cure mouth ulcers. Leaf juice is } \\
\text { diuretic and cathartic. }\end{array}$ \\
\hline & $58377 / 2 n=48$ & & Flowers & $\begin{array}{l}\text { Flowers used to cure boils, piles and sores and used as tonic in } \\
\text { fever, dyspepsia, scabies, dental and liver problems. }\end{array}$ \\
\hline 45. & $\begin{array}{l}\text { S. pseudocapsicum } \\
\text { L./56109/2n=24 }\end{array}$ & Kanthhari & Flowers & Crushed flowers used against asthma and tonsils. \\
\hline 46. & S. viarum Dumal $/ 56080 / 2 \mathrm{n}=24$ & Dudhi & Whole plant & Plant paste is applied to fresh injuries, wounds and boils. \\
\hline 47. & $\begin{array}{l}\text { Sonchus asper } \\
\text { (L.)Hill/57296/2n=18 }\end{array}$ & Dudhi & Whole plant & Plant paste is applied to fresh injuries, wounds and boils. \\
\hline 48. & $\begin{array}{l}\text { S. brachyotus } \\
\text { DC. } / 57302 / 2 \mathrm{n}=18\end{array}$ & Chopalu & Whole plant & $\begin{array}{l}\text { Decoction used to treat stomach problems, dermatitis, } \\
\text { inflammation and ulcers. }\end{array}$ \\
\hline 49. & $\begin{array}{l}\text { Stellaria media }(\mathrm{L} .) \\
\text { Vill./56047/2n=26 }\end{array}$ & Khukhani & Seeds & $\begin{array}{l}\text { Seeds are astringent, carminative and used against asthma, } \\
\text { bronchitis, congestion, obesity, constipation, burns, skin rashes and } \\
\text { kidney problems. }\end{array}$ \\
\hline 50. & $\begin{array}{l}\text { Swertia ciliata } \text { (G. Don) } \\
\text { Burtt } / 56086 / 2 \mathrm{n}=26 \\
58355 / 2 \mathrm{n}=52\end{array}$ & Chiretta & Whole plant & $\begin{array}{l}\text { A bitter tonic used for fever, skin diseases, liver disorders, } \\
\text { dyspepsia, intestinal worms and asthma. }\end{array}$ \\
\hline 51. & $\begin{array}{l}\text { Taraxacum officinale } \\
\text { Wigg./56102/2n=16 }\end{array}$ & $\begin{array}{l}\text { Hand, Dudheri, } \\
\text { Jangli- }\end{array}$ & Rhizome & $\begin{array}{l}\text { A decoction of dry rhizome along with sugar is taken orally twice a } \\
\text { day for 6-7 d during jaundice in kidney and liver problems. }\end{array}$ \\
\hline & $\begin{array}{l}56058 / 2 \mathrm{n}=24 \\
56132 / 2 \mathrm{n}=32\end{array}$ & Surajmookhi & Flowers & $\begin{array}{l}\text { Flower decoction is taken orally in equal proportion with water for } \\
\text { two days to cure boils and blisters. }\end{array}$ \\
\hline 52. & $\begin{array}{l}\text { Thalictrum javanicum } \\
\text { Blume } / 58044 / 2 \mathrm{n}=14\end{array}$ & Mamiri & $\begin{array}{l}\text { Whole plant } \\
\text { Leaves }\end{array}$ & $\begin{array}{l}\text { Plant paste applied externally on wounds. } \\
\text { Juice of leaves is used for eye problems. }\end{array}$ \\
\hline 53. & $\begin{array}{l}\text { Thalapsi arvense } \\
\mathrm{L} . / 56060 / 2 \mathrm{n}=14\end{array}$ & Mithri Sarson & $\begin{array}{l}\text { Seeds } \\
\text { Leaves }\end{array}$ & $\begin{array}{l}\text { Seeds are used in the treatment of pus in the lungs, renal } \\
\text { inflammation, appendicitis, swellings, wounds, cuts and } \\
\text { pulmonary infection. Leaves used as a blood purifier. }\end{array}$ \\
\hline 54. & $\begin{array}{l}\text { Thymus linearis } \\
\text { L./57196/2n=26 }\end{array}$ & Badi-banajwain & $\begin{array}{l}\text { Whole plant } \\
\text { Flowers } \\
\text { Leaves }\end{array}$ & $\begin{array}{l}\text { Decoction of the whole plant is used as an effective home remedy } \\
\text { for curing flu, cold, cough, fever and stomach problems. } \\
\text { The powder of flowers mixed with 'gurr' is given as a vermicide. } \\
\text { Leaves are used as a tonic, cures fever, skin diseases and liver } \\
\text { complaints. }\end{array}$ \\
\hline 55. & $\begin{array}{l}\text { Trifolium repens } \\
\text { L./56337/2n=32 }\end{array}$ & - & Whole plant & $\begin{array}{l}\text { Extract of the whole plant is made to cure a sore throat, } \\
\text { pneumonia, cough, fever, cold and hair dandruff. }\end{array}$ \\
\hline 56. & $\begin{array}{l}\text { Verbascum thapsus } \\
\text { L. } / 58412 / 2 \mathrm{n}=36\end{array}$ & Jangli-Tambaku & Whole plant & $\begin{array}{l}\text { An infusion of the whole plant is used for chest complaints, } \\
\text { diarrhoea and bleeding of gums and lungs. }\end{array}$ \\
\hline 57. & $\begin{array}{l}\text { Viburnum mullaha Buch. Ham. } \\
\text { ex D. Don } \\
/ 58656 / 2 \mathrm{n}=18\end{array}$ & Thalaana & Fruits & Juice of fruits is used to treat indigestion. \\
\hline 58. & Vicia sativa $\mathrm{L} . / 57197 / 2 \mathrm{n}=14$ & Massar & Whole plant & Extract of the plant is used as anti-poison. \\
\hline 59. & $\begin{array}{l}\text { Viola canescens Wall. ex } \\
\text { Roxb./56114/2n=18 }\end{array}$ & Banaksha & $\begin{array}{l}\text { Leaves } \\
\text { Whole plant }\end{array}$ & $\begin{array}{l}\text { Leaf decoction taken orally twice a day to cure cold, cough and malaria. } \\
\text { A decoction of the fresh plant with sugar taken for 3-4 d against } \\
\text { fever, cold, cough, asthma, jaundice and headache. }\end{array}$ \\
\hline 60. & $\begin{array}{l}\text { Withania somnifera } \\
\text { L. } / 56357 / 2 \mathrm{n}=48\end{array}$ & Ashwagandha & $\begin{array}{l}\text { Flowers } \\
\text { Root } \\
\text { Whole plant }\end{array}$ & $\begin{array}{l}\text { Flowers are groundgrinded in milk and given in throat problems. } \\
\text { Roots and whole plant used to treat arthritis, depression, memory } \\
\text { loss and infertility and to increase the iron content in blood. }\end{array}$ \\
\hline 61. & $\begin{array}{l}\text { Xanthium strumarium } \\
\text { L. } / 57315 / 2 \mathrm{n}=36\end{array}$ & Katula & Leaves & $\begin{array}{l}\text { Decoction of leaves is used against malarial fever and as a blood } \\
\text { purifier. Also used to treat leucorrhoea and poisonous bites of } \\
\text { insects, boils and ulcers. }\end{array}$ \\
\hline 62. & $\begin{array}{l}\text { Zanthoxylum armatum } \\
\text { DC./56099/2n=66 }\end{array}$ & Tejfal & $\begin{array}{l}\text { Whole plant } \\
\text { Fruits } \\
\text { Twigs } \\
\text { Seeds Leaves }\end{array}$ & $\begin{array}{l}\text { Decoction of the whole plant is used in malarial fever. } \\
\text { Powdered fruits with dried leaves of Mentha longifolia and } \\
\text { Trachyspermum ammi seeds and black salt is taken with water } \\
\text { thrice a day for 3-4 d during a cough, cholera, fever, stomachache } \\
\text { and indigestion. Twigs chewed during gum problems and } \\
\text { toothache. Seeds are used for piles, leucoderma and snake bite. } \\
\text { Juice of leaves used for renal diseases and antifertility. }\end{array}$ \\
\hline
\end{tabular}




\section{B. Chromosomal status}

Herbs were analyzed for chromosome number, male meiosis and pollen viability. Most of the species are diploid (77.42\%), while 14 species $(22.58 \%)$ exist at different ploidy levels (3x, 4x, 6x, 8x, 12x). Rumex nepalensis $(2 \mathrm{n}=80,120)$, Solanum nigrum $(2 \mathrm{n}=24,48)$, and Taraxacum officinale $(2 n=16,24,32)$ showed the existence of individuals with intraspecific euploid cytotypes while accessions with two chromosome counts of $2 n=18$ and $2 n=26$ were detected in Swertia ciliata $(2 n=26)$. Androsace lanuginosa $(\mathrm{n}=10)$ has been counted chromosomally for the first time from India (fig. 2a), confirming the chromosome count of $2 n=20$ from Pakistan [12]. The diploid count of $n=7$ for Corydalis thyrsiflora (fig. $2 \mathrm{~b}$ ) adds a new dysploid cytotype to the already reported chromosome count of $n=8$ by investigators from Lahaul-Spiti [13] and Kangra district [14], Himachal Pradesh in India. Accesion of Gentiana argentea showed a diploid chromosome count of $n=9$ (fig. 2c), compared with the previous report of $2 n=20$ from other regions of Himalayas [15-16]. Rumex nepalensis, a morphogenetically variable species depicted the existence of two cytotypes $(8 x, 12 x)$ in the valley. The $12 x$ cytotype $(2 n=120)$ has already been reported by investigators from other regions of the Himalayas in India [17] but cytotype $8 \mathrm{x}$ with $2 \mathrm{n}=80$ is the new record for the species (fig. $2 \mathrm{~d}$ ).

\section{Meiotic course and pollen fertility}

Some of the medicinal herbs depicted meiotic irregularities which included cytomixis (fig. 2e), chromatin stickiness (fig. 2f), interbivalent connections (fig. 2g), abnormal spindle (fig. 2h), chromatin bridges (fig. $2 \mathrm{i}$ ) and laggards (fig. $2 \mathrm{j}$ and $2 \mathrm{k}$ ) resulting into abnormal sporads (fig. 2l-2o) and sporads with micronuclei (fig. $2 \mathrm{p}$ and $2 \mathrm{q}$ ) and pollen maformation in form of pollen sterility (fig. $2 \mathrm{r}$ and $2 \mathrm{~s}$ ), micro pollen and fertile pollen grains of varying sizes (fig. $2 \mathrm{t}$ ).

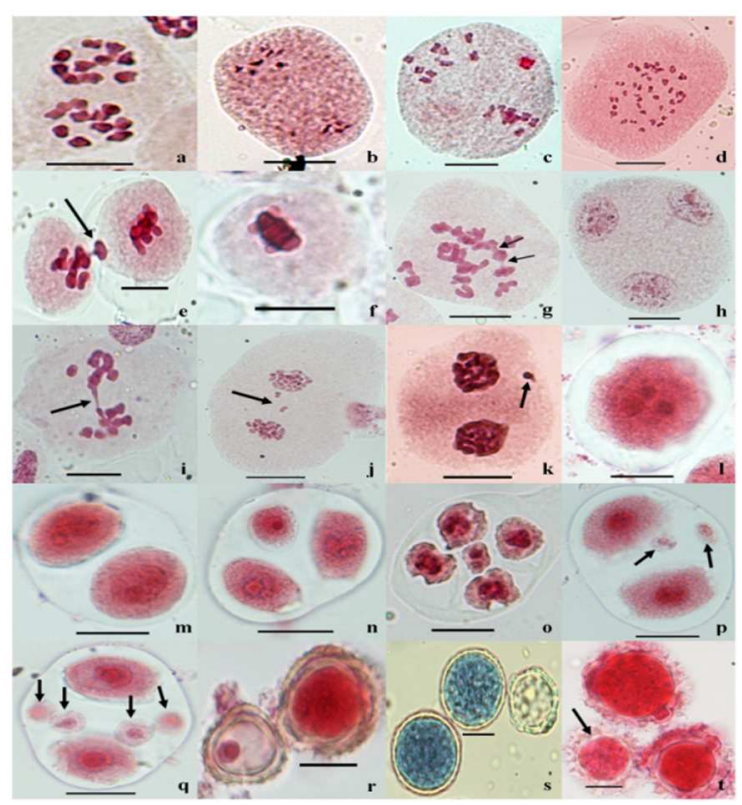

Fig. 2: (Meiotic course) Androsace lanuginosa a) A PMC showing equal distribution of 10:10 chromosomes at A-I. Corydalis thyrsiflora b) A PMC showing equal distribution of $7: 7$ chromosomes at A-I. Gentiana argentea c) A PMC showing equal distribution of 9:9 chromosomes at A-I. Rumex nepalensis d) A PMC showing 40 bivalents at M-I. Cytomixis e) Two PMCs showing chromatin transfer. Chromatin stickiness f) A PMC showing chromatin stickiness at $M$-I. Inter-bivalent connections g) A PMC showing inter-bivalent connections at M-I. Abnormal spindle h) A PMC showing abnormal spindle. Chromatin bridge i) A PMC showing Chromatin Bridge at A-I (arrowed). Laggards j and k) PMCs showing laggards at Late A-I and Telophase-I (arrowed). Abnormal sporads I) Monad. m) Dyad. n) Triad. o) Polyad. p) Dyad with two micronuclei (arrowed). q) Dyad with four micronuclei (arrowed). Pollen grains $r$ and $s$ ) Sterile and fertile pollen grains, t) Heterogeneous sized pollen grains with micro pollen (arrowed). Scale bars $=10 \mu \mathrm{m}$
Such induced meiotic irregularities in the meiocytes involved in cytomixis have already been reported in a number of plants [18-21].

Triploid taxa of Eupatorium adenophorum $(2 \mathrm{n}=51)$ and Taraxacum officinale $(2 n=24)$ showed abnormal meiotic course due to high frequency of univalents, unequal/irregular/scattered distribution of chromosomes and laggards resulting into dyads, triads and sporads with micronuclei and consequently high pollen sterility. Presence of high seed setting in both cases indicates toward their apomictic nature as suggested by some investigators [22].

\section{Chromosomal variation}

Compiled chromosomal information from Indexes to Plant Chromosome Numbers, and internet site, (http://mobot. mobot. org/W3T/Search/ipcn. html) [23], it has been revealed that the medicinal herbs of the valley depicted considerable amount of chromosomal diversity involving aneuploidy and/or poyploidy: Achillea millefolium $(2 \mathrm{x}, 4 \mathrm{x}, 5 \mathrm{x}, 6 \mathrm{x}, 7 \mathrm{x}, 8 \mathrm{x}, 9 \mathrm{x})$, Ajuga parviflora $(2 \mathrm{x}, 4 \mathrm{x})$, Agrimonia eupatoria $(2 \mathrm{x}, 4 \mathrm{x}, 5 \mathrm{x}, 6 \mathrm{x})$, Anemone rivularis $(2 \mathrm{x}, 3 \mathrm{x}, 6 \mathrm{x}$ on $\mathrm{x}=8$; $2 \mathrm{x}, 4 \mathrm{x}$ on $\mathrm{x}=7)$, Artemisia scoparia $(2 \mathrm{x}, 4 \mathrm{x})$, Bidens pilosa $(2 \mathrm{x}, 4 \mathrm{x}, 6 \mathrm{x}, 8 \mathrm{x})$, Cannabis sativa $(2 \mathrm{x}, 4 \mathrm{x}, 8 \mathrm{x})$, Conyza stricta $(2 \mathrm{x}, 4 \mathrm{x})$, Datura stramonium $(2 \mathrm{x}, 4 \mathrm{x})$, Emblica officinalis $(2 \mathrm{x}, 4 \mathrm{x}, 8 \mathrm{x}$ on $\mathrm{x}=13$; $4 \mathrm{x}, 14 \mathrm{x}, 28 \mathrm{x}$ on $\mathrm{x}=14)$, Fagopyrum dibotrys (2x,3x,4x), Geranium lucidum (2x,4x,6x), G. wallichianum $(2 \mathrm{x}, 4 \mathrm{x})$, Hypericum elodeoides $(2 \mathrm{x}, 4 \mathrm{x})$, Lotus corniculatus $(2 \mathrm{x}, 4 \mathrm{x})$, Nepeta laevigata $(2 \mathrm{x}, 4 \mathrm{x})$, Plantago depressa $(2 \mathrm{x}, 4 \mathrm{x}, 6 \mathrm{x}), P$. lanceolata $(2 \mathrm{x}, 4 \mathrm{x}, 6 \mathrm{x})$, P. major $(2 \mathrm{x}, 4 \mathrm{x})$, Ranunculus laetus $(4 \mathrm{x}, 6 \mathrm{x}, 8 \mathrm{x}$ on $\mathrm{x}=7 ; 2 \mathrm{x}, 4 \mathrm{x}$ on $\mathrm{x}=8)$, Rumex nepalensis $(4 \mathrm{x}, 8 \mathrm{x}, 10 \mathrm{x}, 12 \mathrm{x})$, Solanum nigrum $(2 \mathrm{x}, 3 \mathrm{x}, 4 \mathrm{x}, 6 \mathrm{x}, 8 \mathrm{x})$, Sonchus asper $(2 \mathrm{x}, 4 \mathrm{x})$, S. brachyotus $(2 \mathrm{x}, 4 \mathrm{x})$, Taraxacum officinale $(2 \mathrm{x}, 3 \mathrm{x}, 4 \mathrm{x}, 5 \mathrm{x}, 6 \mathrm{x})$, Thalictrum javanicum $(2 \mathrm{x}, 6 \mathrm{x})$, Trifoilium repens $(2 \mathrm{x}, 4 \mathrm{x}, 6 \mathrm{x}, 8 \mathrm{x})$, Vicia sativa $(2 \mathrm{x}, 4 \mathrm{x})$, Viola canescens $(2 \mathrm{x}, 6 \mathrm{x})$, and Withania somnifera $(2 \mathrm{x}, 4 \mathrm{x})$ depicted intraspecific euploid cytotypes. Aneuploidy causing chromosomal variation in these plants is equally common as is apparent from the existence of aneuploid cytotypes in Achillea millefolium $(2 \mathrm{n}=44,45,48,53,74)$, Anemone rivularis $(2 \mathrm{n}=14,16)$, Arctium lappa $(2 \mathrm{n}=32,36)$, Artemisia scoparia $(2 n=16,18)$, Corydalis thyrsiflora $(2 n=14,16)$, Emblica officinalis $(2 \mathrm{n}=26,28,98,104)$, Filipendula vestita $(2 \mathrm{n}=14,18)$, Geranium nepalense $(2 \mathrm{n}=26,28), \quad G$. wallichianum $(2 \mathrm{n}=26,28)$, Impatiens laxiflora $(2 \mathrm{n}=12,14,16)$, Hypericum elodeoides $(2 \mathrm{n}=16,18)$, Lepidium sativum $(2 \mathrm{n}=12,16)$, Lotus corniculatus $(2 \mathrm{n}=28,32,36)$, Origanum vulgare $(2 \mathrm{n}=28,30,32)$, Plantago lanceolata $(2 \mathrm{n}=12,13,14)$, P. major $(2 \mathrm{n}=12$, $16,18,22,23,24)$, Punica granatum $(2 \mathrm{n}=14,15,16,18,19)$, Ranunculus laetus $(2 \mathrm{n}=28,32)$, Rumex hastatus $(2 \mathrm{n}=12,18)$, Sonchus asper $(2 \mathrm{n}=32,36)$, Stellaria media $(2 \mathrm{n}=18,26,28,40,42,44)$, Swertia ciliata $(2 \mathrm{n}=18,20,24,26)$, Thalictrum javanicum $(2 \mathrm{n}=14,16)$, Trifolium repens $(2 \mathrm{n}=16,22,28,30,32)$, Verbascum thapsus $(2 \mathrm{n}=30,34,36,48)$, Taraxacum officinale $(2 \mathrm{n}=16,18,21,23,22-24,26,27,32,34,36,37)$, Thymus linearis $(2 \mathrm{n}=24,26)$, Vicia sativa $(2 \mathrm{n}=12,14)$ and Viola canescens $(2 \mathrm{n}=12,18)$. Further analysis reveals that Achillea millefolium $(2 \mathrm{n}=18,35,36,44,45,48,53,54,60-74,81)$, Aconitum heterophyllum $(2 \mathrm{n}=16,20,24,26,34), \quad$ Agrimonia eupatoria $(2 \mathrm{n}=28,42,56,70,84)$, Bidens pilosa $(2 \mathrm{n}=24,46,48,70,72,76,96)$, Taraxacum officinale $(2 \mathrm{n}=16,18,21,22-24,26,27,32,34,36,37,40$, $48)$ and Viola canescens $(2 \mathrm{n}=10,12,14,16,18,22,26,34)$ seem to constitute species complexes. Existence of such a high chromosomal diversity in these species seems to have been facilitated due to their inherent capacity of reproduction through both sexual and vegetative means coupled with introgressive hybridization.

\section{E. Natural regeneration}

Observations made on natural regeneration revealed that most of them are perennial and propagate through asexual (vegetative and apomictic) means. Vegetative propagation has been noticed to occur through underground parts.

\section{CONCLUSION}

Present work revealed that Parvati Valley is rich in medicinal plants and traditional knowledge. Local people are still relying on traditional knowledge for their healthcare needs. The aspect which needs immediate attention is that flora here is under severe pressure due to various anthropogenic activities. It has been noticed by authors that various medicinal herbs are collected in mass by the traders viz. Viola canescens, Centella asiatica, Ajuga parviflora, 
Arcticum lappa, Berberis glaucocarpa, Thymus linearis, Zanthoxylum armatum, Aconitum heterophyllum, Angelica glauca, Swertia ciliata, etc. Consequently, these medicinal herbs are now left in the form of only a few individuals and fall under the IUCN-World Conservation Union's Red list of threatened species. The problem becomes more serious in Aconitum heterophyllum, Arcticum lappa, Centella asiatica and Swertia ciliata where roots or perennating parts are directly collected from the wild sources. Interestingly, in spite of extensive and intensive surveys, the authors could not find even a single individual of Bergenia stacheyi, Meconopsis aculeata, Pleurospermum candollei, Podophyllum hexandrum, Rheum emodii, Sausserea gossypiphora and Valeriana jatamansi which are listed as important medicinal herbs. And till date, these species have not been included in any of the local conservation plans. The elderly persons, in particular, adivasis, are more aware to this treasure compared to the younger generation. It has been noticed that exposure of younger regeneration to western civilization coupled with limited employment opportunities has posed a serious threat to the gradual diminishing of ethic knowledge. And it will not be surprising that after a span of 20$30 \mathrm{y}$ there will be hardly any person left which will be able to provide information about the plants that at one time were used traditionally for various ethnobotanical and medicinal uses.

Keeping these facts in view, immediate steps must be taken on a priority basis to preserve the ethnic knowledge. And it is also suggested that we should follow this year's UNEP Theme of World Conservation Day as "Go Wild for Life". It envisages you to calibrate all those species under threat and take action of your own to help safeguard them for future generations. It has been rightly said that many local extinctions will eventually add up to global extinction. Furthermore, restrictions on grazing activity should be strictly imposed in alpine and sub-alpine pastures above $3000 \mathrm{~m}$. Present investigations form the basis for exploration of intraspecific morphogenetic diversity especially of the euploid type to detect elite genotypes/chemotypes in these medicinally important plants. Also, there is a need to prepare a database of medicinal plant wealth covering information on ethnomedicinal uses, chromosomal diversity, natural regeneration and distribution pattern which could be used for designing future plans and sustainable development.

\section{ACKNOWLEDGEMENT}

The authors are indebted to the University Grants Commission (UGC), New Delhi, for providing financial support under the DRS SAP I, II and III, ASIST programme, DBT-IPLS (DBT Interdisciplinary Programme of Life Sciences for advanced research and education) and SRF to Rohit Kumar under Rajiv Gandhi National Fellowship [award letter no. F1-17.1/201213/RGNF-2012-13-SC-HIM-18573]. Thanks are also due to head, Department of Botany, Punjabi University, Patiala for necessary laboratory, Herbarium (PUN) and library facilities. The authors are also thankful to local people in the study area for sharing ethnobotanical information for medicinal purposes.

\section{AUTHORS CONTRIBUTION}

Himshikha carried out the work presented in this manuscript. Other authors have contributed to writing and correction of the manuscript.

\section{CONFLICT OF INTERESTS}

The authors declare that they have no conflict of interest

\section{REFERENCES}

1. Uniyal MR, Chauhan NS. Commercially important medicinal plants of Kullu. Forest division of H. P. Nagarjun; 1972.

2. Singh SK, Rawat GS. Traditional verses commercial use of wild medicinal plants of Great Himalayan National Park. Proc Int Mountain Meet 98, Rishikesh; 1998.
3. Singh SK. Ethnobotanical study of useful plants of Kullu district in NW Himalaya. Indian J Econ Taxon Bot 2004;23:185-98.

4. Sharma PK, Chauhan NS, Lal B. Commercial important medicinal and aromatic plants of Parvati Valley of Himachal Pradesh. J Econ Taxon Bot 2003;27:937-42.

5. Sharma PK, Chauhan NS, Lal B. Observation on the traditional phytotherapy among the inhabitants of Parvati Valley in Western Himalayas. Indian J Ethnopharmacol 2004;92:167-76.

6. Sharma PK, Chauhan NS, Lal B. Studies on plant-associated indigenous knowledge among the Malanis of Kullu district, Himachal Pradesh. Indian J Trad Knowl 2005;27:4403-8.

7. Lone PA, Bhardwaj AK. Traditional herbal based disease treatment in some rural areas of Bandipora district of Jammu and Kashmir, India. Asian J Pharm Clin Res 2013;6:162-71.

8. Periyasamy K, Kaliyaperumal S. Ethnobotanical, phytochemical and pharmaceutical studies of medicinal plant, Ventilago Maderaspatana Gaertn (Red Creeper): a review. Int J Curr Pharm Res 2015;8:16-8.

9. Sharma V, Chaudhary U. An overview on indigenous knowledge of Achyranthes aspera. J Crit Rev 2015;2:7-19.

10. Kumari K, Saggoo MIS. Male meiosis and morphometric analysis of ethnobotanically important Allium carolinianum DC. from Kinnaur district of Himachal Pradesh, India. Asian J Pharm Clin Res 2016;9:396-8.

11. Dhaliwal DS, Sharma M. Flora of kullu district (Himachal Pradesh). Bishen Singh Mahendra Pal Singh, Dehra Dun; 1999.

12. Khatoon Ali SI. Chromosomal atlas of the angiosperms of Pakistan. Department of Botany, University of Karachi, Karachi; 1993.

13. Kumar P, Singhal VK. Chromosome number, male meiosis and pollen fertility in selected angiosperms of the cold deserts of Lahaul-Spiti and adjoining areas (Himachal Pradesh, India). Plant Syst Evol 2011;297:271-97.

14. Rani S, Kumari S, Gupta RC, Chahota RK. Cytological studies of angiosperms (174 species) from District Kangra, Himachal Pradesh (India). Plant Syst Evol 2013;300:851-62.

15. Mehra PN, Vasudevan KN. IOPB chromosome number reports XXXVI. Taxon 1972;21:333-46.

16. Bala S, Malik RA, Gupta RC. New chromosome counts in some gentians from Western Himalayas. Caryologia 2015;68:147-53.

17. Mehra PN, Dhawan H. Cytotaxonomy of some N. Indian Polygonaceae. Proc 53rd Indian Sci Congr Part 3; 1966. p. 277.

18. Singhal VK, Kumar P, Kaur D, Rana PK. Chromatin transfer during male meiosis resulted into heterogeneous sized pollen grains in Anemone rivularis Buch.-Ham. ex DC. from Indian cold deserts. Cytologia 2009;74:229-34.

19. Kumar P, Singhal VK, Kaur D, Kaur S. Cytomixis and associated meiotic abnormalities affecting pollen fertility in Clematis orientalis. Biol Plantarum 2010;54:181-4.

20. Guan JZ, Wang JJ, Cheng ZH, Liu Y, Li ZY. Cytomixis and meiotic abnormalities during microsporogenesis are responsible for male sterility and chromosomal variations in Houttuynia cordata. Genet Mol Res 2012;11:121-30.

21. Rana PK, Kumar P, Singhal VK. Cytomixis and associated abnormalities during male meiosis in Lindelofia longiflora var. falconeri (Boraginaceae). Cytologia 2014;79:535-40.

22. Mehra PN, Gill BS, Mehta JK, Sidhu SS. Cytological investigations on the Indian Compositae. I. North Indian taxa. Caryologia 1965;18:35-68.

23. http://mobot.mobot.org/W3T/Search/ipcn.html. [Last accessed on 20 Jun 2017]

\section{How to cite this article}

- Himshikha, Raghbir Chand Gupta, Vijay Kumar Singhal, Rohit Kumar. Ethnomedicinal notes and chromosomal status of some selected herbs from Parvati Valley, Kullu District, Himachal Pradesh. Int J Pharm Pharm Sci 2017;9(10):191-196. 